\title{
Unhealthy Conditions? A Longitudinal Analysis of the Health of Children in One- and Two-parent Households
}

\author{
Hilke Brockmann
}

\begin{abstract}
Families produce health, but changes in familial structures are made responsible for many negative health trends in the population. How does the health of younger children today in Germany develop when comparing whether the parents live together or separately? Using data from the German Socio-Economic Panel Study (SOEP), we are able to show that children in traditional marriages are not generally healthier than children in other families. For example, the risk of suffering health problems is even significantly lower among younger children of single mothers than among children of married mothers. Nevertheless, children of married mothers have a higher birth weight and a body mass index (BMI) that deviates less from the norm than the children of divorced mothers. Longitudinally and under control of possible selection effects, there is evidence that the separation and divorce of parents has negative health effects. Especially the mental and intellectual state of the mother, rather than her material situation, can help to cushion the negative consequences of a separation on her children's health. Against the background of increasing numbers of single mothers, we will discuss the current and future significance of these findings.
\end{abstract}

Keyword: Health · Children · Single Mothers · Longitudinal Analysis · Germany

\section{Introduction}

The seventh Family Report emphasises the importance of the family as the "producer of common goods" and as a "private social network of special quality" (Bundestag 2006: 6, translated by CPoS). Familial networks produce health. For almost 200 years and apparently regardless of a constantly growing professionalised health system, demographers have repeatedly proven that married people live longer than unmarried people (Brockmann/Klein 2004). Children and older people also profit in a number of ways from familial support (Amato 2000; Beets et al. 2010; Hammons) Fiese 2011; Hudson/Payne 2011; James/Lessen 2009; Wolff/Roter 2011). 
At the same time, however, studies also make familial structures partly responsible for the dramatically rising number of obese children (Ebbeling et al. 2002; Gundersen et al. 2011), for the increasing physical and psychological developmental disorders of adolescents (Bradley/Corwyn 2002; Collishaw et al. 2004; Klocke/ Becker 2003) and their poor medical care and prevention (Horstkotte/Zimmermann 2008).

The major familial changes of the past decades were often seen as the trigger of these negative trends. Figure 1 illustrates these changes in German families.

Fig. 1: New family types in Germany

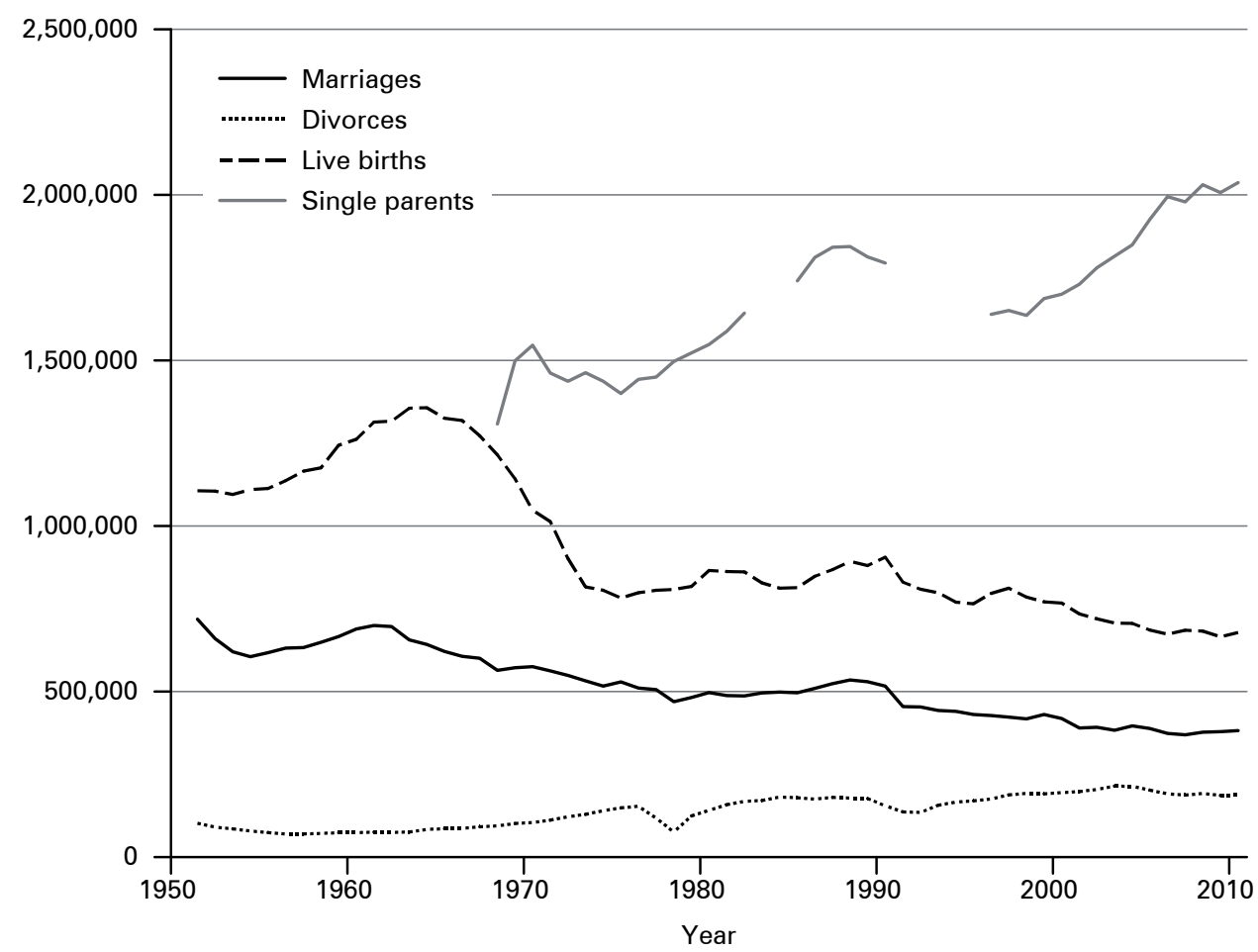

Source: Statistisches Bundesamt 2011

Many studies confirm that high divorce rates, an increasing number of unmarried parents and a continuously growing group of single parents produce less healthy conditions than the biological cohabiting two-parent family (Kelleher et al. 2000; Schmeer 2011; Sigle-Rushtonet al. 2005; Troxel/Matthews 2004).

However, there are also contrary findings. More recent longitudinal studies in particular show that the traditional family is by no means directly and exclusively superior to other family models. For example, Artis (2007) proves that loneliness and sadness among children at preschool age can be completely explained by the availability of economic resources, the depression of the mother and by parental 
child-raising practices. Walper and Beckh (2006) use German longitudinal data to show that it is not necessarily the familial structure, but the temporary transition that leads to symptoms of depression among young people (9-19 years of age).

This analysis attempts to break down these contradicting results more precisely by testing the range and the explanatory content of the assumptions about singleparent households and the health of their children more exhaustively. Precisely: Can the findings on the impact of familial changes, most of which are based on North American, often non-representative data, also hold out in a representative German longitudinal sample? And how strong is their impact on the health of younger children? To answer these research questions, we use the representative German Socio-Economic Pane/ Study. These are reliable, up-to-date longitudinal data that allow us to purposefully link information about mothers, households and children at preschool age in order to better understand complex health processes in families over time. As there are no informative data on twins and adopted children, we statistically exclude genetic influences in panel analyses.

The article is structured as follows: After the introduction, we provide an overview of the research background from which we derive three hypotheses. In the third section, we describe the methodological procedure and the data set. This is followed by a portrayal of the findings and a concluding discussion of the results against the background of previous research.

\section{Research background}

\subsection{Marital status and health - an adult perspective}

Regardless of the institutional changes in marriage, even today data prove that married men and women live significantly longer than unmarried people (Gove 1973; Hu/Goldman 1990; Manzoli et al. 2007; Sorlie et al. 1995). From longitudinal studies we also know that divorce and the death of a partner can greatly impair one's health for a certain time (Johnson et al. 2000; Wade/Pevalin 2004).

These robust findings are often explained by the loss of the protective factor of a life-long relationship. Married couples usually possess more material prosperity. They are able to help one another and care for one another in times of illness. Moreover, married couples have a less risky, healthier lifestyle (Waldron et al. 1996; Wyke/Ford 1992). In addition to this protective effect of marriage, longitudinal data also show evidence of selection effects. Healthier people have better chances of finding a spouse and of staying married (Brockmann/Klein 2004; Joung et al. 1998; Lillard/Panis 1996). It is unclear how robust these causal and selective effects are over the course of familial change. 


\subsection{Marital status of mothers and their children's health}

\subsubsection{Causal influences}

It is well substantiated that children profit from their parents' marriage (Amato 2001; Amato/Sobolewski 2001). Both in the liberal US welfare state as well as in socialdemocratic Sweden, infant mortality is significantly lower when mothers are married (Arntzen et al. 1996; Balayla et al. 2011; Bennett 1992). Disparate health prerequisites also remain through the course of a lifetime. Children of married parents are healthier throughout their entire childhood and into adulthood (Angel/Worobey 1988; Hayward/Gorman 2004).

Divorces are a special test case for studying the causality between marital status and child health. Cause and effect can be chronologically differentiated. Hence, the study of the consequences of divorce for children has always taken up a great deal of space in the literature as well (Amato 1993).

Current longitudinal studies often confirm the negative effects of divorce ascertained in the cross-section. Children of divorced parents are disadvantaged in a number of aspects; also their physical and psychological health is affected ( $\mathrm{Am}$ ato 2010). Using a representative Canadian sample, Strohschein (2005) was able to show that children suffer significantly more often from depression, anxiety and anti-social behavioural problems, both directly prior to their parents' divorce and over the course of the process. Tucker et al. (1997) use the data from the Termen Life Cycle Study (1921-1991) to ascertain the long-term effects of a divorce. Childhood experience of divorce actually breeds more risky and negligent behaviour in adulthood (smoking, education) and a shorter life expectancy.

Researchers explain the negative health effects experienced by children of divorced parents with a stress theory that places the strenuous and costly adjustments to separation by one parent in the focus. The frequent loss of parental support, the often insufficient contact to the father, continued conflicts between mother and father, economic losses and other stress-related events correlated with divorce force children to undergo a re-orientation, which, in the least favourable case, involves a short-term crisis and can - but not must - in the long term become a chronic burden (Amato 2000: 1271).

Moderator variables - variables that contribute to the effect of separation risks on the health of children - reveal more in-depth insights. The influence of individual, interpersonal and structural resources has been indicated many times in the literature. Studies show that household income, the mental stability of the parents, but also the household's social involvement are influential (Car/son/Corcoran 2001; Cavanagh 2008; Fabricius/Luecken 2007). The quality of the marriage and the openly conducted conflicts during separation also prove to be important moderator variables. The more destructive the conflicts between the parents are experienced, the significantly higher is the probability that children will suffer from a mental disorder (Booth/Amato 2001; Schick 2002; Troxel/Matthews 2004; Walper/Beckh 2006). It is not yet thoroughly researched, but plausible, whether and the extent to which the time of the divorce in relation to the age of the children, the time passed since the 
divorce and the historical context are also important influence parameters (Rattay et al. 2012; Schick 2002).

\subsubsection{Selective influences}

The causal explanation of health-damaging divorce consequences conflicts with selection effects. The health differences between the children of divorced and nondivorced parents could be influenced by factors that already existed before the marriage. Studies of twins and siblings refer to genetic self-selection in broken homes (Cleveland et al. 2000; McGue/Lykken 1992). More recent studies use findings from molecular biology for the first time to directly show that specific genetic polymorphisms cause risky and health-endangering behaviours that interact with social and also with familial processes (Guo et al. 2008). It is also possible that genetically inherited diseases restrict the options of choosing a suitable partner, thus leading to higher separation and divorce rates.

These and other possible influences that already affected the health of children prior to a divorce can be statistically controlled using longitudinal data, for instance through panel models with fixed effects. These models exclusively take changes since the divorce into consideration and mask time-constant effects. Fixed effects serve to best control for genetically related health problems in children. An interaction of genetic dispositions and environmental influences, however, that first have an effect following the separation of families, such as a genetically inherited propensity to risky, health-endangering behaviour, cannot be taken into account in these designs.

Nevertheless, the findings of existing panel analyses are contradictory. Some studies continue to confirm a causal correlation between divorce and health disadvantages, while others do not. For example, independent of selection effects, Cherlin, Chase-Lansdale, and McRae (1998) ascertain that young British adults with divorced parents have greater psychological problems. Gruber (2004) shows that although the elimination of the principle of fault in American divorce law lowers the threshold for divorce and thus (negative) selection in a divorce, the new divorce law nonetheless leads to a higher suicide rate. By contrast, in the longitudinal data of the US birth cohorts of 1957-64 (NLSY79), Aughinbaugh, Pierret and Rothstein (2005) discover no statistically significant correlation between divorce and child behavioural problems.

Therefore, research still needs to be done. Neither the choice of health variables, nor of moderators, nor variables that have major impacts on divorce effects are standardised in studies. It has in no way been clarified whether differing, objective and subjective health indicators or rather strongly correlated, chronologically changing, objective socio-economic or subjective psychological moderators are not responsible for these inconsistent findings. It is also unclear whether all moderators are equally effective at all times and in all national contexts.

We therefore test the stress theory of divorce effects based on various health variables. We also examine the importance of the cited objective influencing factors simultaneously in a model. We then use the current and representative German 
panel data to ascertain the causal effect of the mothers' marital status on the health of their children. Thus, the following hypotheses guide our analysis:

H1: Any form of dissolution of a familial unit causes negative stress and therefore has a disadvantageous effect on the health of dependent children.

H2: Objective and subjective parental resources can frequently compensate for the negative influence of missing parents.

H3: The health of the children has a selective influence on the failure of couple relationships.

The influence of parental resources $(\mathrm{H} 2)$ is falsely assessed when the selective influence of the health of children on the failure of couple relationships $(\mathrm{H} 3)$ is not taken into account.

\section{Data and methodology}

The analysis is based on data from the German Socio-Economic Pane/ Study, which is conducted annually by the German Institute for Economic Research (DIW). It starts with the biographical data of mothers and their newborn and small children surveyed since 2002 . The study includes 1,825 children of 1,420 mothers. Information about the health and social circumstances both directly after birth and at the ages of 2 to 3 years are available for 1,035 children. Another survey at the ages of 5 to 6 years was completed among 445 children, whereby 355 of the children had then already taken part in the survey for the third time.

According to the definition by the WHO $(1948 / 2006),{ }^{1}$ health is a multi-dimensional construct. We measure health using objective and subjective, curative and preventive indicators. Birth weight and also later deviations from the usual standard indicators such as the body mass index (BMI) are often used and are meaningful measurements of physiological fitness to assess the health of children. Another important characteristic of children's health are infantile disorders, which were surveyed in a very general way. In addition to these objective physical measurements, we also take the subjective assessment of mothers on the health of their children into consideration. And, finally, preventive and curative medical measures that may be reflected in sufficient medical care are particularly important for the long-term health of children. We therefore also incorporate demands for medical services.

Information can be obtained about the earlier, present and later life and health situation of the mothers through access to various survey waves of the SOEP. Table 1 shows further characteristics of the familial network and additional control variables used in the study in more detail.

1 Exact wording of the definition of health by the WHO: „Health is a state of complete physical, mental and social well-being and not merely the absence of disease or infirmity." (1948/2006: 1) 
Tab. 1: Descriptive distributions in the SOEP data set (2002-2009)

\begin{tabular}{|c|c|c|c|c|}
\hline \multirow[b]{2}{*}{ Children } & \multicolumn{2}{|c|}{$\mathrm{N}(\%)$} & \multicolumn{2}{|c|}{ Mean (SD) } \\
\hline & & & & \\
\hline In total & 1825 & & & \\
\hline With 2 measurements & 1035 & & & \\
\hline With 3 measurements & 355 & & & \\
\hline Age (in years) & & & 2.1 & (1.8) \\
\hline Girls & 800 & & & \\
\hline \multicolumn{5}{|l|}{ Marital status } \\
\hline Married living together & 2326 & (73.5) & & \\
\hline Married living separately & 58 & $(1.8)$ & & \\
\hline Single & 608 & $(19.2)$ & & \\
\hline Divorced & 160 & $(5.1)$ & & \\
\hline Widowed & 13 & $(0.4)$ & & \\
\hline \multicolumn{5}{|l|}{ Changes in marital status } \\
\hline In total & 146 & & & \\
\hline $\begin{array}{l}\text { Separations of married couples } 8 \\
\text { widowhood }\end{array}$ & 58 & & & \\
\hline Birth weight (in grams) & & & 3332 & (628) \\
\hline Weight at $2-3$ years (in kilograms) & & & 14.1 & $(2.5)$ \\
\hline Weight at $5-6$ years (in kilograms) & & & 21.3 & (4.0) \\
\hline \multicolumn{5}{|l|}{ BMI } \\
\hline $0-1$ year & & & 12.7 & (1.65) \\
\hline $2-3$ years & & & 15.94 & (3.3) \\
\hline $5-6$ years & & & 15.7 & (2.8) \\
\hline \multicolumn{5}{|c|}{ Number of visits to the doctor in the first/last 3 months } \\
\hline $0-1$ year-olds & & & 1.4 & $(2.8)$ \\
\hline $5-6$ year-olds & & & 1.6 & (2.0) \\
\hline \multicolumn{5}{|c|}{ Duration of hospital stays in the first/last 3 months (in days) } \\
\hline $0-1$ year-olds & & & 1.7 & $(8.1)$ \\
\hline 2-3 year-olds & & & 0.7 & (5.4) \\
\hline 5-6 year-olds & & & 0.4 & (1.9) \\
\hline \multicolumn{5}{|l|}{ No physical disorders identified (\%) } \\
\hline $0-1$ year $(\%)$ & 1522 & (94) & & \\
\hline $2-3$ years $(\%)$ & 76 & (58) & & \\
\hline $5-6$ years $(\%)$ & 31 & (49) & & \\
\hline \multicolumn{5}{|l|}{ Worried about the health of the child } \\
\hline \multirow{2}{*}{$0-1$ year to a large extent $(\%)$} & 69 & $(4.0)$ & & \\
\hline & 156 & (8.9) & & \\
\hline $2-3$ years to a large extent & 55 & (4.8) & & \\
\hline to a moderate extent & 96 & (8.4) & & \\
\hline \multicolumn{5}{|l|}{ Mothers } \\
\hline In total & 1420 & & & \\
\hline Age (in years) & & & 32.7 & (5.9) \\
\hline Life satisfaction ${ }^{a}$ & & & 7.5 & (1.6) \\
\hline Years of education & & & 12.7 & $(2.7)$ \\
\hline
\end{tabular}




\section{Continuation Tab. 1}

\begin{tabular}{|c|c|c|c|c|}
\hline \multirow[b]{2}{*}{ Subjective health } & \multicolumn{2}{|c|}{$\mathrm{N}(\%)$} & \multicolumn{2}{|c|}{ Mean (SD) } \\
\hline & & & & \\
\hline Very good and good & 1003 & (73) & & \\
\hline Not so good and poor & 82 & (6) & & \\
\hline \multicolumn{5}{|l|}{ SF12 Short-Form Health Survey ${ }^{b}$} \\
\hline Physiological health & & & 54.5 & $(6.7)$ \\
\hline Mental health & & & 48.6 & (9.7) \\
\hline \multicolumn{5}{|l|}{ Satisfaction with own health } \\
\hline 0 completely dissatisfied 10 completely satisfied & & & 7.6 & $(1.8)$ \\
\hline \multicolumn{5}{|l|}{ Nationality (\%) } \\
\hline German & 1250 & (90) & & \\
\hline Turkish & 47 & (4) & & \\
\hline \multicolumn{5}{|l|}{ Household } \\
\hline In total & & & 1258 & \\
\hline Net income (in euro) & & & 2376 & 1433) \\
\hline Number of persons living in the household & & & 3.6 & $(1.1)$ \\
\hline Number of children living in the household & & & 1.9 & $(1.0)$ \\
\hline
\end{tabular}

a Measured with: "Taking all things together, how satisfied are you with your life?" 0 means "completely dissatisfied" 10 means "completely satisfied"

b Ware et al. 1996

Source: German Socio-Economic Panel, own calculations

We evaluate the data in various regression analyses. Regressions with chronologically summarised data (pooled ordinary least square regressions) ${ }^{2}$ determine the relative significance of familial and individual influencing factors on the child's health. Robust variance estimators provide for autocorrelation of the measurements. In fixed-effects panel models, we then narrow the analytical view of changes (Wooldridge 2010). Divorce and other forms of familial dissolution are included in the models as discrete events. Their influence on changes in the health of the children is estimated. The individual heterogeneity and selectivity of the children and mothers is controlled for to ensure largely causal attributions. We thereby understand causality not exclusively as a result of a manipulative experiment, but further and in conformity with other social scientists as a generative, mechanical process that links an earlier cause to a later result (Blossfeld et al. 2009).

2 OLS regressions are based on the estimation method of the smallest squared deviations. Depending on the prefixes, the designated coefficients indicate a positive or negative influence of a determinant on the dependent variable. This (partial) influence is measured as a modification of the dependent variables such as a rise on a health scale through an increase in the independent variables by one measurement unit, such as a rise of 1,000 euros income. The other influences are constant or controlled in this case. The overall effect results finally from the addition of all partial influences. 


\section{$4 \quad$ Results}

The analysis of the range of our hypotheses portrayed below in detail indicates no persistent disadvantages to children of single mothers. In the cross section, familial separations play a subordinated role. They often correlate with specific socio-economic variables. The panel model does, however, indicate negative consequences on the health of children following their parents' divorce.

\subsection{The weight of children in various family structures}

A breakdown of children's health according to the marital status of the mothers shows - in conformity with hypothesis 1 - that the children of single mothers have a significantly lower birth weight than those of married mothers. The difference to single but still married or formerly married mothers is, however, only of minor significance due to the large dispersion within these groups. A more precise breakdown reveals though that children of widowed mothers weigh significantly less than the children of married mothers by an average of 413 grams (not shown). But this difference in weight does not last. The BMI of children of single mothers until the age of six no longer deviates significantly from those of mothers of other marital statuses. Therefore, hypothesis 1 is only partially confirmed.

Specific socio-economic circumstances are often linked to the actual familial situation. Multivariate models break down these correlations statistically and examine whether existing differences or analogies endure (hypothesis 2). The models shown in Tables 2, 3 and 4 are based on the measurements from all three of the survey waves.

Table 2 shows that an unmarried status still has a negative effect when also controlled for other weight-relevant influences such as the week of gestation at birth and socio-economic variables, which all have no significant influence on the birth weight. The highly correlating health and socio-economic variables are also not moderator variables that suddenly reveal a hidden correlation of body mass index and marital status. With regard to the birth weight and deviations from the BMI, the German data therefore do not confirm hypothesis 2.

\subsection{Objective health disorders and subjective worries}

Physical and mental disorders can lastingly endanger the healthy development of children. The German Socio-Economic Panel Study contains a number of surveyed disorders, which can only be used as a dichotomous variable (yes or no) here due to the low number of cases. The coefficients illustrated in the first column of Table 3 are odds ratios. ${ }^{3}$

3 An odds ratio indicates the probability relative to value 1 with which an independent variable alters the (dichotomous) characteristics of the dependent variables. 
Tab. 2: Influence on the health of young children

\begin{tabular}{|c|c|c|c|c|c|c|}
\hline \multirow[b]{2}{*}{ Constant } & \multicolumn{3}{|c|}{$\begin{array}{l}\text { Birth weight } \\
\text { (in grams) }\end{array}$} & \multicolumn{3}{|c|}{ Deviations from median BMI } \\
\hline & $\begin{array}{l}3375^{* * *} \\
(20)\end{array}$ & $\begin{array}{l}-2966 * * * \\
(571)\end{array}$ & $\begin{array}{l}-2749 * * * \\
(484)\end{array}$ & $\begin{array}{l}2.8^{* * *} \\
(0.05)\end{array}$ & $\begin{array}{l}15.2^{* * *} \\
(1.4)\end{array}$ & $\begin{array}{l}13.8^{* * *} \\
(1.0)\end{array}$ \\
\hline $\begin{array}{l}\text { Family breakup } \\
\text { (separation, divorce, death) }\end{array}$ & ns & $\begin{array}{c}-106.5^{+} \\
(64.1)\end{array}$ & $\begin{array}{c}-113.2^{+} \\
(68.2)\end{array}$ & ns & ns & ns \\
\hline $\begin{array}{l}\text { Single } \\
\text { Ref.: married }\end{array}$ & $\begin{array}{l}-89.9^{*} \\
(36.9)\end{array}$ & $\begin{array}{l}-139.9 * * \\
(46.2)\end{array}$ & $\begin{array}{l}-134.3^{* *} \\
(45.9)\end{array}$ & ns & ns & ns \\
\hline Weeks of gestation & & $\begin{array}{l}149.8^{* * *} \\
(10)\end{array}$ & $\begin{array}{l}153.7^{* * *} \\
(12.2)\end{array}$ & & $\begin{array}{l}-0.25^{* * *} \\
(0.03)\end{array}$ & $\begin{array}{l}-0.26 * * * \\
(0.02)\end{array}$ \\
\hline Age of the child & & ns & & & $\begin{array}{l}-0.05^{* * *} \\
(0.01)\end{array}$ & $\begin{array}{l}-0.04 * * * \\
(0.01)\end{array}$ \\
\hline \multicolumn{7}{|l|}{ Health of the mother } \\
\hline Age & & ns & & & $\begin{array}{l}-0.02^{+} \\
(0.01)\end{array}$ & \\
\hline \multicolumn{7}{|l|}{ Household characteristics } \\
\hline $\begin{array}{l}\text { Number of children in the } \\
\text { household }\end{array}$ & & & $\begin{array}{r}74^{+} \\
(41.9)\end{array}$ & & & $\begin{array}{l}-0.21^{*} \\
(0.1)\end{array}$ \\
\hline $\mathrm{R}^{2}$ & 0.5 & 34.8 & 36 & 0.00 & 18.4 & 16.8 \\
\hline $\mathrm{N}$ & 1591 & 1087 & 1057 & 1796 & 692 & 1635 \\
\hline
\end{tabular}

*** $\mathrm{p}<0.001 * * \mathrm{p}<0.01 * \mathrm{p}<0.05+\mathrm{p}<0.1$

Note: Pooled OLS models with robust variance estimations for auto-correlated data clusters. Standard errors in brackets. Subjective health, deviation from norm BMI, SF12, satisfaction with health as well as education and unemployment of the mother and the net household income are controlled for and not significant.

Source: SOEP (1984) 2002-2009

Contrary to the expectation expressed in hypothesis 1, disorders are ascertained significantly less often ( 41 percent) among children of families broken up by separation, divorce or the death of a parent than among children of married mothers. Children of single mothers, on the other hand, have a 76 percent higher risk of suffering health disorders than children of the married reference group. Nonetheless, single mothers worry significantly less about the health of their children than all other mothers.

The influence of a mother's marital status on the objective and subjectively assessed health of her child fades when we also take the age of the child, the mental health of the mother and the household socio-economic situation into consideration.

In concrete terms, with every year of age of the child, the probability that he or she will suffer from a disorder drops by 12-13 percent annually until the sixth year of age. The rise in the psychological well-being of mothers is accompanied by a reduction in the probability that their children suffer health disorders. The case numbers 
Tab. 3: Influence on the objective and subjective health of young children

\begin{tabular}{|c|c|c|c|c|c|c|c|}
\hline \multirow[b]{2}{*}{ Constant } & \multicolumn{3}{|c|}{$\begin{array}{l}\text { Health disorders } \\
\text { Yes/No } \\
\text { OR/z }(S D) \quad \\
\end{array}$} & \multicolumn{4}{|c|}{$\begin{array}{l}\text { Worries about health of the child } \\
1=\text { to a large extent }-4=\text { not at all } \\
B / t \text { (SD) }\end{array}$} \\
\hline & & & & $\begin{array}{l}3.42^{* * *} \\
(0.02)\end{array}$ & $\begin{array}{c}1.69^{*} \\
(0.85)\end{array}$ & $\begin{array}{l}1.68^{* * *} \\
(0.49)\end{array}$ & $\begin{array}{l}2.83^{* * * *} \\
(0.59)\end{array}$ \\
\hline $\begin{array}{l}\text { Family breakup (separation, divorce, } \\
\text { death) }\end{array}$ & $\begin{array}{l}0.59^{*} \\
(0.14)\end{array}$ & ns & ns & ns & ns & ns & ns \\
\hline Single Ref.: married & $\begin{array}{l}1.76^{*} \\
(0.44)\end{array}$ & ns & ns & $\begin{array}{l}0.12^{* *} \\
(0.05)\end{array}$ & ns & ns & ns \\
\hline Weeks of gestation & & ns & & & ns & & \\
\hline Age of the child & & $\begin{array}{l}0.88^{* * *} \\
(0.01)\end{array}$ & $\begin{array}{l}0.87^{* * *} \\
(0.01)\end{array}$ & & ns & & \\
\hline \multicolumn{8}{|l|}{ Health disorders } \\
\hline Motoric & & & & & & & $\begin{array}{l}0.48^{* * *} \\
(0.08)\end{array}$ \\
\hline Neurological & & & & & & & $\begin{array}{l}-0.97^{*} \\
(0.42)\end{array}$ \\
\hline Chronic illness & & & & & & & $\begin{array}{l}-1.72^{* * *} \\
(0.16)\end{array}$ \\
\hline $\begin{array}{l}\text { Physical disability } \\
\text { Ref.: no disorder in the } 1^{\text {st }} \text { year }\end{array}$ & & & & & & & $\begin{array}{l}0.57^{* * *} \\
(0.14)\end{array}$ \\
\hline Visits to the doctor & & & & & & & $\begin{array}{l}0.07^{* *} \\
(0.02)\end{array}$ \\
\hline Days in hospital & & & & & & & $\begin{array}{l}-0.02^{*} \\
(0.01)\end{array}$ \\
\hline \multicolumn{8}{|l|}{ Health of the mother } \\
\hline Age & & ns & & & ns & & \\
\hline Subjective health & & ns & & & ns & & \\
\hline Absolute deviation from BMI norm & & ns & & & $\begin{array}{c}0.02^{*} \\
(0.007)\end{array}$ & $\begin{array}{l}0.015^{*} \\
(0.007)\end{array}$ & ns \\
\hline \multicolumn{8}{|l|}{ SF12 Short-Form Health Survey ${ }^{a}$} \\
\hline Physiological health & & ns & & & $\begin{array}{r}0.01^{+} \\
(0.006)\end{array}$ & $\begin{array}{l}0.01^{*} \\
(0.005)\end{array}$ & ns \\
\hline Mental health & & $\begin{array}{l}0.95^{*} \\
(0.02)\end{array}$ & $\begin{array}{l}0.96^{*} \\
(0.02)\end{array}$ & & $\begin{array}{l}0.01^{* * *} \\
(0.003)\end{array}$ & $\begin{array}{l}0.01^{* * *} \\
(0.003)\end{array}$ & ns \\
\hline Satisfaction with health & & & ns & & & ns & \\
\hline Education of mother & & & ns & & & $\begin{array}{c}-0.01^{+} \\
(0.007)\end{array}$ & ns \\
\hline \multicolumn{8}{|l|}{ Household characteristics } \\
\hline Net household income (log) & & & $\begin{array}{l}3.1^{*} \\
(1.67)\end{array}$ & & & ns & \\
\hline Persons in household & & & ns & & & ns & \\
\hline Number of children in household & & & ns & & & ns & \\
\hline $\begin{array}{l}\text { Log pseudo LL } \\
\text { (Pseudo) } R^{2}\end{array}$ & -601.5 & -100.3 & -120.8 & & & & \\
\hline (Pseudo) $\mathrm{R}^{2}$ & 0.4 & 54 & 53 & 0.4 & 4 & 5 & 19.4 \\
\hline $\mathrm{N}$ & 2968 & 1090 & 1133 & 2582 & 938 & 949 & 220 \\
\hline
\end{tabular}

Note: The models are based on pooled logit and OLS regressions with robust variance estimations for auto-correlated data clusters.

Source: SOEP (1984) 2002-2009

are, however, too low to longitudinally identify whether the mental well-being of the mother causes a disorder in the child or vice versa the childhood disorder negatively impairs the mental health of the mother.

Contrary to our expectations, the household income significantly increases the probability of a disorder diagnosis. A rise in income from 1,000 to 10,000 euros tri- 
ples the risk that a health disorder is diagnosed in the child. One explanation for this counterintuitive finding is that the income-independent insurance status motivated doctors to use more costly diagnostic measures. For the income effect is lost when we control for the type of health insurance (private/statutory). If we take this into consideration without the household income, the children of mothers with private health insurance have health disorders significantly more frequently (not shown). Based on the data, however, we cannot entirely eliminate the possibility that lower income groups are less sensitive to disorders or deviations or that they perhaps do not admit to negative diagnoses due to their social undesirability.

The subjective assessment of the child's health is quite different. The mother's income does not come into play; instead her own health is decisive. Mothers whose weight deviates from the BMI norm and with lower physical and mental well-being worry significantly more about the health of their children. The variance explanation of this model $\left(R^{2}\right)$, meaning the quality of the statistical explanation, is however unsatisfactorily low at 5 percent.

We therefore calculate another model in which variables on the objective health of the child are also incorporated. These absorb all of the effects of the mother, which shows that mother and child health correlate highly. We will attempt to identify the causal correlations more precisely with a longitudinal analysis. However, with almost 20 percent $\left(R^{2}\right)$, we achieve acceptable model quality for a sociological field study. For these analyses, it is also important that the individual findings are comparable.

\subsection{Doctor and hospital visits}

Parents control their children's demand for medical care. The mother's marital status plays a significant role in the number of health check-ups and hospital stays. All of the models in Table 4 prove that the children of single mothers spend more time in hospital than the children of married mothers.

The value fluctuates by one-third of a day and increases if we additionally control for health influencing factors and socio-economic determinants. In these more complex calculations, the duration of hospital stays of children of divorced, separated or widowed mothers also differ from that of single mothers. They are significantly shorter (not shown).

Socio-economic influences, by contrast, play no role in the hospital care of children in Germany. This is a good finding, although it partially disproves our second hypothesis with regard to hospital care.

Regardless of the socio-economic situation of the household, mothers take advantage of the free outpatient screening examinations during their children's first year. The finding that separated mothers take advantage of this offer significantly less often is, however, eliminated by the educational variables. In addition, the number of visits to the doctor with small children is hardly related to the socio-economic circumstances of the mother. Solely household income and tentatively the number of children in the household have effects. Contra-intuitively and apparently inconsistent with hypothesis 2 , a higher net household income lowers the number 


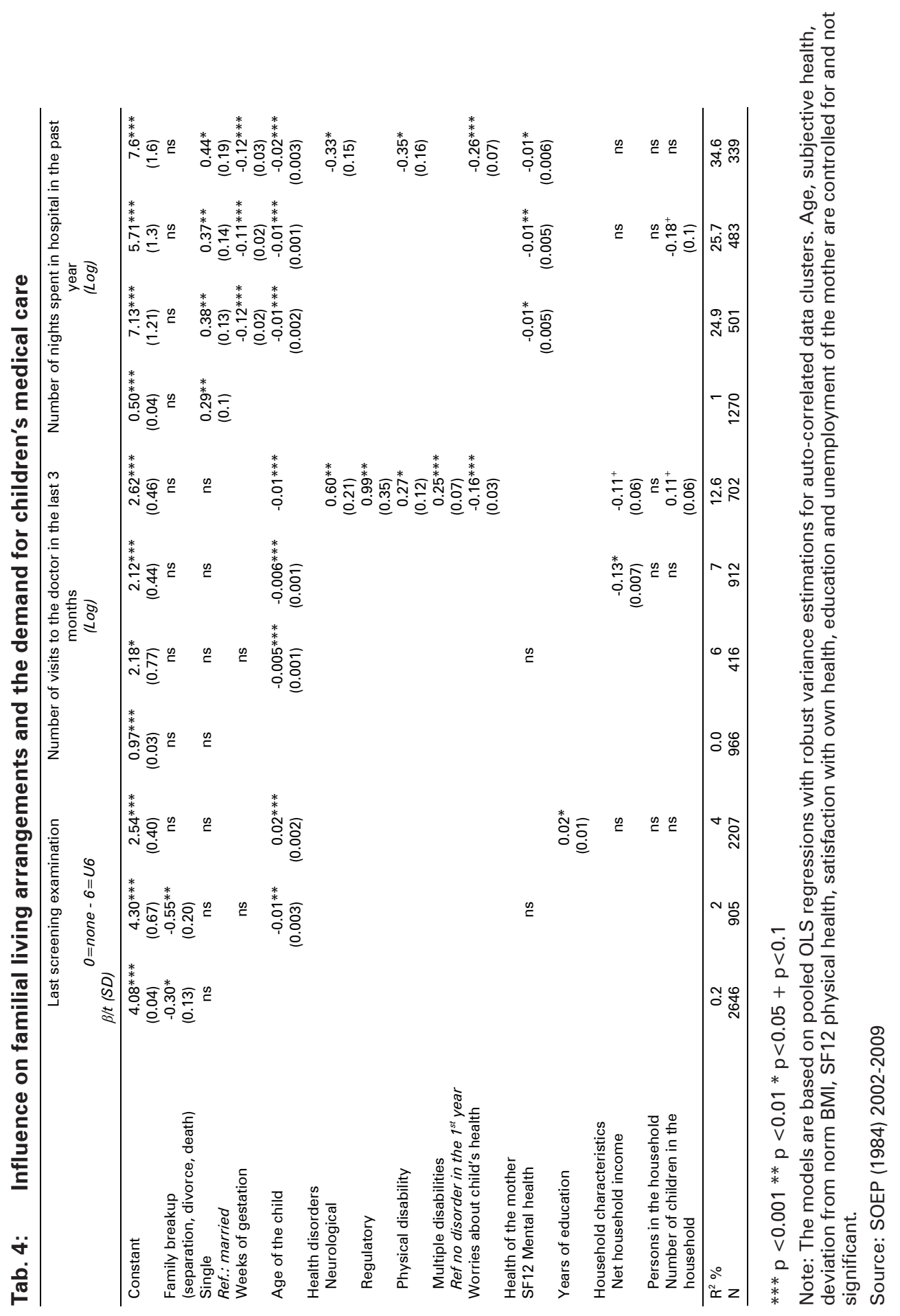


of visits to the doctor. At second glance, however, this finding can actually be explained in conformity with our expectations, because higher income is beneficial to health and therefore visits to the doctor ought to be needed less often.

\subsection{Divorce or selection effects}

Only a panel analysis enables us to separate causality and selection effects and thus reliably estimate their respective influences on health. The fixed-effects panel models in Table 5 control for the individual heterogeneity of children and parents, even - and this is decisive for our analysis - for their health prior to possible divorces, separations or deaths in the family. Now, only changes in child health caused by changed familial constellations and by the other cited time-changeable variables are explained. Constant (health) variables, such as birth weight and the number of screening examinations, cannot be taken into consideration.

Unlike cross-sectional analyses of the compiled data and consistent with hypothesis 3, the panel analysis reveals that the divorce of parents has quite lasting health-relevant consequences. When parents divorce, the child's BMI deviates significantly from the age-adequate norm by over 3 units. This finding is also robust when taking further moderator variables into account and confirms a causal effect that was hidden by a positive selection, i.e. that an above-average number of mothers of healthy children take the step of divorce, which is why the effect is not visible in the cross section.

Table 5 also shows that with the exception of the time of birth in weeks of gestation and the age of the child at the survey, neither the household income, mother's education nor other influencing variables not shown here like the mother's employment status, her health status or her subjective satisfaction with her health, the household size or number of children in the household are statistically significant.

The number of visits to the doctor also drops significantly when parents divorce. But this effect fades when the age of the child, the net household income, the subjective worries about the health of the child and health disorders are statistically controlled.

Moreover, the longitudinal analysis confirms the correlation of increasing household income and decreasing number of visits to the doctor. Against the background of the international discussion - primarily in the United States - about access to medical services, this finding appears odd. In the German context, it indicates the disparate behaviours in utilisation and the unequal health status of persons who have statutory and private health insurance (Hullegie/Klein 2010).

Finally, unlike the initial models, separation from a married partner compared to the traditional cohabiting two-parent family proves to be a significant influencing factor on the subjective assessment of the child's health if we also control for the educational level of the mother. Other significant effects that became apparent in a cross-sectional analysis, in particular comparing single and married mothers, are not identified in a longitudinal analysis, but are identified indirectly as health-relevant selection effects in the marriage that are controlled for by the panel model. 
Tab. 5: Familial changes and child health

\begin{tabular}{|c|c|c|c|c|c|c|c|c|}
\hline \multirow[b]{2}{*}{ Change into the status ... } & \multicolumn{2}{|c|}{$\begin{array}{l}\text { Deviations from mean } \\
\text { BMl } \\
\beta / t(S D)\end{array}$} & \multicolumn{2}{|c|}{ Worries } & \multicolumn{2}{|c|}{$\begin{array}{l}\text { Visits to the doctor } \\
\text { (log) }\end{array}$} & \multicolumn{2}{|c|}{$\begin{array}{l}\text { Hospital nights } \\
\text { (log) }\end{array}$} \\
\hline & & & & & & & & \\
\hline Single & ns & ns & ns & ns & $\begin{array}{c}0.27^{+} \\
(0.16)\end{array}$ & ns & ns & ns \\
\hline Married living separately & ns & ns & ns & $\begin{array}{l}-2.01^{*} \\
(0.9)\end{array}$ & ns & ns & ns & ns \\
\hline Divorced & $\begin{array}{l}3.43^{* *} \\
(1.3)\end{array}$ & $\begin{array}{l}3.18^{*} \\
(1.46)\end{array}$ & ns & ns & $\begin{array}{l}-0.55^{* *} \\
(0.20)\end{array}$ & ns & ns & ns \\
\hline $\begin{array}{l}\text { Widowed } \\
\text { Reference: married }\end{array}$ & ns & ns & ns & ns & ns & ns & ns & ns \\
\hline Weeks of gestation & & $\begin{array}{l}-0.31 * * * \\
(0.08)\end{array}$ & & & & & & $\begin{array}{l}-0.26^{* * *} \\
(0.04)\end{array}$ \\
\hline Age of the child & & $\begin{array}{l}-0.05^{* * * *} \\
(0.01)\end{array}$ & & & & $\begin{array}{l}-0.01 * * * \\
(0.002)\end{array}$ & & $\begin{array}{l}-0.02 * * * \\
(0.006)\end{array}$ \\
\hline $\begin{array}{l}\text { Health disorders } \\
\text { (Yes/No) }\end{array}$ & & & & & & $\begin{array}{l}0.98^{* *} \\
(0.35)\end{array}$ & & ns \\
\hline Worries about health of child & & & & & & $\begin{array}{l}-0.11^{*} \\
(0.06)\end{array}$ & & $\begin{array}{l}-0.08^{+} \\
(0.04)\end{array}$ \\
\hline Age of the mother & & & & & & & & $\begin{array}{l}0.20 * * \\
(0.07)\end{array}$ \\
\hline Education of the mother & & & & $\begin{array}{l}0.8^{*} \\
(0.39)\end{array}$ & & & & \\
\hline $\begin{array}{l}\text { Household characteristics } \\
\text { Net household income } \\
\text { (log) }\end{array}$ & & & & & & $\begin{array}{l}-0.41^{* *} \\
(0.16)\end{array}$ & & \\
\hline $\mathrm{R}^{2} \%$ (within) & 2.9 & 21.3 & 0.2 & 13.4 & 3.8 & 21 & 0.8 & 28.7 \\
\hline $\mathrm{N}$ & 1187 & 1107 & 1864 & 312 & 859 & 643 & 1116 & 754 \\
\hline
\end{tabular}

*** $p<0.001 * * p<0.01 * p<0.05+p<0.1$

Note: The models are based on fixed-effects panel regressions. All significant moderator variables from previous models are controlled.

Source: SOEP (1984) 2002-2009

\section{Discussion}

It has long been recognised that families generate health, but disciplinary boundaries between health and family research impede the systematic exchange of results. In this paper, we link findings from international family research concerning familial change with pertinent, preclinical measurements of health. We test the influence of familial structures and the influence of their changes on the health of children using little-researched representative German data.

Our analysis shows that children living in traditional marriages in Germany are not generally healthier than children in other families. Differentiated reasoning is needed; more differentiated than often employed in US studies (Waite/Gallagher 2000). Children of married mothers have a higher birth weight, which is an indicator of less stress (Torche 2011). Their BMI also deviates less from the norm than that of children of divorced mothers. But there is no difference in the BMI of children of single and widowed mothers. In addition and contrary to general expectations, the risk that children of separated mothers suffer from health disorders is significantly lower. 
The marital status also correlates with unequal socio-structural realities. The often cited better financial situation of the cohabiting two-parent family is not necessarily beneficial to health in the German context. The income of the parents has no impact on most of the health variables examined here. The fact that a higher net household income correlates with the probability of children suffering a health disorder instead indicates unintentional, supply-induced demand effects of the health system (Brockmann et al. 2006; Jürges 2007). Privately insured children of higherearning parents pay higher treatment fees, and it is therefore possible that they are over-treated. A more explicit test of this argument would, however, require more extensive data than those underlying this study and therefore must be conducted elsewhere.

The mental and intellectual condition of mothers, who filter the effects of familial changes, is more decisive for the health and well-being of children than are material resources. From the literature, we know that married people are happier and better educated on average than unmarried people (Coombs 1991; Lucas et al. 2003; Stack/Eshleman 1998; Torr 2011). Yet, we are also aware that relationships differ quite considerably in quality (Bradbury et al. 2000). People, and women in particular who still file for the most divorces, may perceive the disentanglement from an unsatisfactory relationship more as a happy gain than as a stressful loss (Amato) Booth 2001; Andress/Brockel 2007; Umberson/Montez 2010). Caring for a gravely ill spouse can also be a burden (Christakis/Iwashyna 2003; Horowitz et al. 1996), especially when children in the household also require care. The loss of these burdens may explain why separations, divorces and even the death of a partner often do not impair the health of the child.

But positive selection effects are also indirectly verifiable: When we control for the individual heterogeneity in the panel model and only incorporate the direct effect of observed divorces and other family separations on the health of children, then we see negative health consequences that were hidden in the pooled longitudinal data. For instance, children of divorced mothers have a significantly deviating $\mathrm{BMI}$ and separated mothers worry more about the health of their children. Nonetheless, divorced mothers consult doctors significantly less and separated mothers do not go to the doctor more frequently than married or single mothers, who worry less about the health of their children.

The data as such do not provide any information about the type of selection, and the panel results are chronologically limited to a maximum of 5 years following a divorce/separation. But for this time period, the findings confirm that the transitional experience of a separation or divorce are certainly unsettling and strenuous for all involved. The new life circumstances directly impair eating and athletic behaviours of children and the demand for health services. However, changes in marital status do not trigger alarming clinical effects, which can be identified through lengthy hospital stays.

The data set does not allow for further breakdown of the development of health following a divorce. The sample for the longitudinal analysis of infantile health disorders is too small. In addition, health disorders were only surveyed quite generally. We can also not claim to have made an exhaustive choice of health indicators. We 
also must suppress long-term health consequences. And finally, simultaneous data on the relationship quality - that could more precisely record the significance of familial structures and their changes - as well as genetic information are lacking.

In spite of these limitations, the differentiated findings provide important insights within the German context and offer further components for international research on families and health. We confirm that families that do not fit into the conventional model of the cohabiting two-parent family also promote the health of their children in Germany. Yet, we also see that particularly children of single mothers are disadvantaged in many cases. These disadvantages are partly the result of negative selection processes, for the prevalent causal influencing factors do not entirely grasp the distinctiveness of the single-parent status. In addition to genetic factors, early maternal illnesses are also possible. A direct test would require genetic data and/ or a twin design.

In future however, we cannot expect that the rising number of single mothers will be accompanied by a parallel rise in health problems in these families. Along with familial change, the status of a single mother will be increasingly less negatively selected, because ever more women voluntarily choose to remain unmarried when they have children. The concrete burdens on single parents in everyday life will, however, remain or may even worsen. They by all means deserve more scientific and social attention.

One additional enlightening aspect of our study is the fact that in Germany a lack of material resources does not acutely influence the health of children. This is a very major difference to many international and primarily American findings and an affirmation of the German public health system. However, the German health system ought to react with more sensitivity to the mental problems of mothers and of ongoing divorce and separation crises, for they have negative effects on the acute and preventive health care of children. Future studies should more precisely examine this correlation, for it has lasting epidemiological and economic consequences.

\section{Acknowledgements}

I would like to thank the two anonymous reviewers for their critical comments on an earlier version of this paper as well as the editors of this volume, the translator and the journal for their support.

\section{References}

Amato, Paul R. 1993: Children's Adjustment to Divorce: Theories, Hypotheses, and Empirical Support. In: Journal of Marriage and Family 55,1: 23-38 [doi: 10.2307/352954].

Amato, Paul R. 2000: The Consequences of Divorce for Adults and Children. In: Journal of Marriage and Family 62,4: 1269-1287 [doi: 10.1111/j.1741-3737.2000.01269.x].

Amato, Paul R. 2001: Children of divorce in the 1990s: An update of the Amato and Keith (1991) meta-analysis. In: Journal of Family Psychology 15,3: 355-370 [doi: 10.1037/0893-3200.15.3.355]. 
Amato, Paul R. 2010: The Marriage-Go-Round: The State of Marriage and the Family in America Today. In: Journal of Marriage and Family 72,5: 1455-1457 [doi: 10.1111/j.17413737.2010.00777.x].

Amato, Paul R.; Sobolewski, Juliane M. 2001: The Effects of Divorce and Marital Discord on Adult Children's Psychological Well-Being. In: American Sociological Review 66,6: 900-921 [doi: 10.2307/3088878].

Amato, Paul R.; Booth, Alan 2001: The legacy of parents' marital discord: Consequences for children's marital quality. In: Journal of Personality and Social Psychology 81,4: 627-638 [doi: 10.1037//0022-3514.81.4.627].

Andreß, Hans-Jürgen; Bröckel, Miriam 2007: Income and life satisfaction after marital disruption in Germany. In: Journal of Marriage and Family 69,2: 500-512 [doi: 10.1111/j.1741-3737.2007.00379.x].

Angel, Ronald; Worobey, Jacqueline Lowe 1988: Single Motherhood and Childrens Health. Journal of Health and Social Behavior 29,1: 38-52

Arntzen, Annett; Moum, Torbjorn; Magnus, Per; Bakketeig, Leiv S. 1996: Marital Status as a Risk Factor for Fetal and Infant Mortality. In: Scandinavian Journal of Social Medicine 24,1: 36-42 [doi: 10.1177/140349489602400106].

Artis, Julie E. 2007: Maternal Cohabitation and Child Well-Being Among Kindergarten Children. In: Journal of Marriage and Family 69,1: 222-236 [doi: 10.1111/j.17413737.2006.00355.x].

Aughinbaugh, Alison; Pierret, Charles R.; Rothstein, Donna S. 2005: The impact of family structure transitions on youth achievement: Evidence from the children of the NLSY79. In: Demography 42,3: 447-468 [doi: 10.1353/dem.2005.0023].

Balayla, Jacques; Azoulay, Laurent; Abenhaim, Haim A. 2011: Maternal Marital Status and the Risk of Stillbirth and Infant Death: A Population-Based Cohort Study on 40 Million Births in the United States. In: Womens Health Issues 21,5: 361-365 [doi: 10.1016/j. whi.2011.04.001].

Beets, Michael W., Cardinal, Bradley J.; Alderman, Brandon L. 2010: Parental Social Support and the Physical Activity-Related Behaviours of Youth: A Review. In: Health Education \& Behavior 37,5: 621-644 [doi: 10.1177/1090198110363884].

Bennett, Trude 1992: Marital-Status and Infant Health Outcomes. In: Social Science \& Medicine 35,9: 1179-1187.

Blossfeld, Hans-Peter; Schneider, Thorsten; Doll, Jörg 2009: Methodological Advantages of Panel Studies. Designing the New National Educational Panel Study (NEPS) in Germany. In: Journal of Educational Research Online 1,1: 10-32.

Booth, Alan; Amato, Paul R. 2001: Parental Predivorce Relations and Offspring Postdivorce Well-Being. In: Journal of Marriage and Family 63,1: 197-212 [doi: 10.1111/j.17413737.2001.00197.x].

Bradbury, Thomas N.; Fincham, Frank D.; Beach, Steven R. H. 2000: Research on the Nature and Determinants of Marital Satisfaction: A Decade in Review. In: Journal of Marriage and Family 62,4: 964-980 [doi: 10.1111/j.1741-3737.2000.00964.x].

Bradley, Robert H.; Corwyn, Robert F. 2002: Socioeconomic Status and Child Development. Annual Review of Psychology, 53: 371-399 [doi: 10.1146/annurev. psych.53.100901.135233].

Brockmann, Hilke; Klein, Thomas 2004: Love and Death in Germany: The Marital Biography and Its Effect on Mortality. In: Journal of Marriage and Family 66,3: 567-581 [doi: 10.1111/j.0022-2445.2004.00038.x]. 
Brockmann, Hilke; Müller, Rolf; Voges, Wolfgang 2006: Auch ein Reformeffekt? Eine explorative Analyse der zunehmenden Krankenhausbehandlungen auf Grund psychischer Störungen. In: Das Gesundheitswesen 68,10: 626-632 [doi: 10.1055/s-2006-927069].

Deutscher Bundestag 2006: Siebter Familienbericht. Familie zwischen Flexibilität und Verlässlichkeit - Perspektiven für eine lebenslaufbezogene Familienpolitik. Bundestagsdrucksache Berlin: Deutscher Bundestag

Carlson, Marcia J.; Corcoran, Mary E. 2001: Family Structure and Children's Behavioral and Cognitive Outcomes. In: Journal of Marriage and Family 63,3: 779-792 [doi: 10.1111/j.1741-3737.2001.00779.x].

Cavanagh, Shannon E. 2008: Family Structure History and Adolescent Adjustment. In: Journal of Family Issues 29,7: 944-980 [doi: 10.1177/0192513X07311232].

Cherlin, Andrew J.; Chase-Lansdale, P. Lindsay; McRae, Christine 1998: Effects of Parental Divorce on Mental Health Throughout the Life Course. In: American Sociological Review 63,2: 239-249 [doi: 10.2307/2657325].

Christakis, Nicholas A.; Iwashyna, Theodore J. 2003: The health impact of health care on families: a matched cohort study of hospice use by decedents and mortality outcomes in surviving, widowed spouses. In: Social Science \& Medicine 57,3: 465-475 [doi: 10.1016/s0277-9536(02)00370-2].

Cleveland, H. Harrington; Wiebe, Richard P.; van den Oord, Edwin J. C. G.; Rowe, David C. 2000: Behavior Problems among Children from Different Family Structures: The Influence of Genetic Self-Selection. In: Child Development 71,3: 733-751 [doi: 10.1111/1467-8624.00182].

Collishaw, Stephan; Maughan, Barbara; Goodman, Robert; Pickles, Andrew 2004: Time trends in adolescent mental health. In: Journal of Child Psychology and Psychiatry 45,8: 1350-1362 [doi: 10.1111/j.1469-7610.2004.00335.x]

Coombs, Robert H. 1991: Marital Status and Personal Well-Being: A Literature Review. In: Family Relations 40,1: 97-102 [doi: 10.2307/585665].

Ebbeling, Cara B.; Pawlak, Dorota B.; Ludwig, David S. 2002: Childhood obesity: publichealth crisis, common sense cure. In: THE LANCET 360,9331: 473-482 [doi: 10.1016/ S0140-6736(02)09678-2].

Fabricius, William V.; Luecken, Linda J. 2007: Postdivorce living arrangements, parent conflict, and long-term physical health correlates for children of divorce. In: Journal of Family Psychology 21,2: 195-205 [doi: 10.1037/0893-3200.21.2.195].

Gove, Walter R. 1973: Sex, Marital Status, and Mortality. In: American Journal of Sociology 79,1: 45-67.

Gruber, Jonathan 2004: Is Making Divorce Easier Bad for Children? The Long-Run Implications of Unilateral Divorce. In: Journal of Labor Economics 22,4: 799-833 [doi: 10.1086/423155].

Gundersen, Craig; Mahatmaya, Duhita; Garasky, Steven; Lohman, Brenda J. 2011: Linking psychosocial stressors and childhood obesity. In: Obesity Reviews 12,5: e54-e63 [doi: 10.1111/j.1467-789X.2010.00813.x].

Guo, Guang; Roettger, Michael E.; Cai, Tianji 2008: The Integration of Genetic Propensities into Social-Control Models of Delinquency and Voilence among Male Youths. In: American Sociological Review 73,4: 543-568 [doi: 10.1177/000312240807300402].

Hammons, Amber J.; Fiese, Barbara H. 2011: Is frequency of shared family meals related to the nutritional health of children and adolescents? In: Journal of the American Academy of Paediatrics 127,6: Ee1565-E1574. 
Hayward, Mark D.; Gorman, Bridget K. 2004: The long arm of childhood: The influence of early-life social conditions on men's mortality. In: Demography 41,1: 87-107 [doi: 10.1353/dem.2004.0005].

Horowitz, Sharon; Passik, Steven D.; Malkin, Mark G. 1996: "In sickness and in health": A Group Intervention for Spouses Caring for Patients with Brain Tumors. In: Journal of Psychosocial Oncology 14,2: 43-56 [doi: 10.1300/j077v14n02_03].

Horstkotte, Elisabeth; Zimmermann, Eberhard 2008: Unequal Living Conditions and Health Chances in Preschool Children: Support Protective Factors - Limit Risk Factors. In: Gesundheitswesen 70,11: 662-666 [doi: 10.1055/s-0028-1100398].

Hu, Yuanreng R.; Goldman, Noreen 1990: Mortality Differentials by Marital-Status: An International Comparison. In: Demography 27,2: 233-250 [doi: 10.2307/2061451].

Hudson, Peter; Payne, Sheila 2011: Family Caregivers and Palliative Care: Current Status and Agenda for the Future. In: Journal of Palliative Medicine 14,7: 864-869 [doi: 10.1089/jpm.2010.0413].

Hullegie, Patrick; Klein, Tobias J. 2010: The effect of private health insurance on medical care utilization and self-assessed health in Germany. In: Health Economics 19,9: 1048-1062 [doi: 10.1002/hec.1642].

James, D. C.; Lessen, R. 2009: Position of the American Dietetic Association: promoting and supporting breastfeeding. In: Journal of the American Dietetic Association 109,11: 1926-1942 [doi: 10.1016/j.jada.2009.09.018].

Johnson, Norman J.; Backlund, Eric; Sorlie, Paul D.; Loveless, Catherine A. 2000: Marital Status and Mortality: The National Longitudinal Mortality Study. In: Annals of Epidemiology 10,4: 224-238.

Joung, Inez M. A. et al. 1998: A Longitudinal study of health selection in marital transitions. In: Social Science \& Medicine 46,3: 425-435

Jürges, Hendrik 2007: Health insurance status and physician-induced demand for medical services in Germany: new evidence from combined district and individual level data. SOEP Papers on Multidisciplinary Panel Data Research at DIW Berlin.

Kelleher, Kelly J. et al. 2000: Increasing identification of psychosocial problems 1979-1996. In: Pediatrics 105,6: 1313-1321 [doi: 10.1542/peds.105.6.1313].

Klocke, Andreas; Becker, Ulrich 2003: Die Lebenswelt Familie und ihre Auswirkungen auf die Gesundheit von Jugendlichen. In: Hurrelmann, Klaus; Klocke, Andreas; Melzer, Wolfgang; Ravens-Sieberer, Ulrike (Hrsg.): Jugendgesundheitssurvey. Internationale Vergleichsstudie im Auftrag der Weltgesundheitsorganisation (WHO). Weinheim: Juventa: 183-241.

Lillard, Lee A.; Panis, Constantijn W. A. 1996: Marital status and mortality: The role of health. In: Demography 33,3: 313-327 [doi: 10.2307/2061764].

Lucas, Richard E.; Clark, Andrew E.; Georgellis, Yannis; Diener, Ed 2003: Reexamining adaptation and the set point model of happiness: Reactions to changes in marital status In: Journal of Personality and Social Psychology 84,3: 527-539 [doi: 10.1037//0022-3514.84.3.527].

Manzoli, Lamberto; Villari, Paolo; Pirone, Giovanni M.; Boccia, Antonio 2007: Marital status and mortality in the elderly: A systematic review and meta-analysis. In: Social Science and Medicine 64,1: 77-94 [doi: 10.1016/j.socscimed.2006.08.031].

McGue, Matt; Lykken, David T. 1992: Genetic Influence on Risk of Divorce. In: Psychological Science 3,6: 368-373 [doi: 10.1111/j.1467-9280.1992.tb00049.x]. 
Rattay, Petra; Lampert, Thomas; Neuhauser, Hannelore; Ellert, Ute 2012: Bedeutung der familialen Lebenswelt für die Gesundheit von Kindern und Jugendlichen. Ergebnisse des Kinder- und Jugendgesundheitssurveys (KiGGS). Zeitschrift für Erziehungswissenschaften 15,1: 145-170 [doi: 10.1007/s11618-012-0261-4].

Schick, Andreas, 2002: Behavioral and emotional differences between children of divorce and children from intact families: Clinical significance and mediating processes. In: Swiss Journal of Psychology 61,1: 5-14 [doi: 10.1024//1421-0185.61.1.5].

Schmeer, Kammi K. 2011: The Child Health Disadvantage of Parental Cohabitation. In: Journal of Marriage and Family 73,1: 181-193 [doi: 10.1111/j.1741-3737.2010.00797.x].

Sigle-Rushton, Wendy; Hobcraft, John; Kiernan, Kathleen 2005: Parental divorce and subsequent disadvantage: a cross-cohort comparison. In: Demography 42,3: 427-446 [doi: 10.1353/dem.2005.0026].

Sorlie, Paul D.; Backlund, Eric; Keller, Jacob B. 1995: US Mortality by Economic, Demographic, and Social Characteristics: The National Longitudinal Mortality Study. In: American Journal of Public Health 85,7: 949-956 [doi: 10.2105/AJPH.85.7.949].

Stack, Steven; Eshleman, J. Ross 1998: Marital Status and Happiness: A 17-Nation Study. In: Journal of Marriage and Family 60,2: 527-536 [doi: 10.2307/353867].

Statistisches Bundesamt 2011: Bevölkerung. Wiesbaden [https://www.destatis.de/DE/ ZahlenFakten/GesellschaftStaat/Bevoelkerung/Bevoelkerung.html, 30.09.2013].

Strohschein, Lisa 2005: Parental Divorce and Child Mental Health Trajectories. In: Journal of Marriage and Family 67,5: 1286-1300 [doi: 10.1111/j.1741-3737.2005.00217.x].

Torche, Florencia 2011: The Effect of Maternal Stress on Birth Outcomes: Exploiting a Natural Experiment. In: Demography 48,4: 1473-1491 [doi: 10.1007/s13524-0110054-z].

Torr, Berna M. 2011: The Changing Relationship between Education and Marriage in the United States, 1940-2000. In: Journal of Family History 36,4: 483-503 [doi: 10.1177/0363199011416760].

Troxel, Wendy M.; Matthews, K.aren A. 2004: What Are the Costs of Marital Conflict and Dissolution to Children's Physical Health. In: Clinical Child and Family Psychology Review 7,1: 29-57 [doi: 10.1023/B:CCFP.0000020191.73542.b0].

Tucker, Joan S. et al. 1997: Parental divorce: Effects on individual behavior and longevity. In: Journal of Personality and Social Psychology 73,2: 381-391 [doi: 10.1037/0022-3514.73.2.381].

Umberson, Debra; Montez, Jennifer Karas 2010: Social Relationships and Health: A Flashpoint for Health Policy. In: Journal of Health and Social Behavior 51,1: S54-S66 [doi: 10.1177/0022146510383501].

Wade, Terrance J.; Pevalin, David J. 2004: Marital Transitions and Mental Health. In: Journal of Health and Social Behavior 45,2: 155-170 [doi: 10.1177/002214650404500203].

Waite, Linda J.; Gallagher, Maggie 2000: The Case for Marriage: Why Married People are Happier, Healthier, and Better off Financially. New York: Doubleday.

Waldron, Ingrid; Hughes, Mary Elisabeth; Brooks, Tracy L. 1996: Marriage protection and marriage selection - Prospective evidence for reciprocal effects of marital status and health. In: Social Science \& Medicine 43,1: 113-123 [doi: 10.1016/0277-9536(95)00347-9]. 
Walper, Sabine; Beckh, Katharina 2006: Adolescents' Development in High-Conflict and Separated Families. Evidence from a German Longitudinal Study. In: ClarkeStewart, Alison; Dunn, Judy (Hrsg.): Families Count. Effects on Child and Adolescent Development. Cambridge, MA: Cambrigde University Press: 238-270 [doi: 10.1017/ CBO9780511616259].

Ware, John E.; Kosinski, Mark; Keller, Susan D. 1996: A 12-Item Short-Form Health Survey: Construction of scales and preliminary tests of reliability and validity. In: Medical Care 34,3: 220-233.

WHO 1948/2006: Constitution of the World Health Organization [URL: http://www.who. int/governance/eb/who_constitution_en.pdf, 10.09.2013].

Wolff, Jennifer L.; Roter, Debra L. 2011: Family presence in routine medical visits. In: Social Science \& Medicine 72,6: 823-831 [doi: 10.1016/j.socscimed.2011.01.015].

Wooldridge, Jeffrey M. 2010: Econometric Analysis of Cross Section and Panel Data. Cambridge, MA: MIT Press.

Wyke, Sally; Ford, Graeme 1992: Competing explanations for associations between marital status and health. In: Social Science \& Medicine 34,5: 523-532 [doi: 10.1016/0277-9536(92)90208-8].

Translated from the original text by the Federal Institute for Population Research, for information only. The reviewed and author's authorised original article in German is available under the title "Ungesunde Verhältnisse? Eine Längsschnittanalyse zur Gesundheit von Kindern in zusammenund getrenntlebenden Familien", DOI 10.4232/10.CPOS-2013-16de or URN urn:nbn:de:bib-cpos2013-16de1, at http://www.comparativepopulationstudies.de.

Date of submission: 20.10 .2011

Date of Acceptance: 18.09 .2012

Prof. Dr. Hilke Brockmann ( $₫)$. Jacobs University Bremen, 28725 Bremen, Germany. E-Mail: h.brockmann@jacobs-university.de

URL: https://www.jacobs-university.de/shss/hbrockmann 


\section{Comparative Population Studies - Zeitschrift für Bevölkerungswissenschaft}

wWw.comparativepopulationstudies.de

ISSN: 1869-8980 (Print) - 1869-8999 (Internet)

Published by / Herausgegeben von

Prof. Dr. Norbert F. Schneider

Federal Institute for Population Research

D-65180 Wiesbaden / Germany

Managing Editor /

Verantwortlicher Redakteur

Frank Swiaczny

Assistant Managing Editor /

Stellvertretende Redakteurin

Katrin Schiefer

Language \& Copy Editor (English) /

Lektorat \& Übersetzungen (englisch)

Amelie Franke

Copy Editor (German) /

Lektorat (deutsch)

Dr. Evelyn Grünheid

\section{Layout / Satz}

Beatriz Feiler-Fuchs

E-mail: cpos@bib.bund.de

\author{
Scientific Advisory Board / \\ Wissenschaftlicher Beirat \\ Jürgen Dorbritz (Wiesbaden) \\ Paul Gans (Mannheim) \\ Johannes Huinink (Bremen) \\ Marc Luy (Wien) \\ Clara H. Mulder (Groningen) \\ Notburga Ott (Bochum) \\ Peter Preisendörfer (Mainz)
}

\section{Board of Reviewers / Gutachterbeirat} Martin Abraham (Erlangen)

Laura Bernardi (Lausanne) Hansjörg Bucher (Bonn) Claudia Diehl (Göttingen) Andreas Diekmann (Zürich) Gabriele Doblhammer-Reiter (Rostock) Henriette Engelhardt-Wölfler (Bamberg) E.-Jürgen Flöthmann (Bielefeld) Alexia Fürnkranz-Prskawetz (Wien) Beat Fux (Zürich) Joshua Goldstein (Rostock) Karsten Hank (Köln) Sonja Haug (Regensburg) Franz-Josef Kemper (Berlin) † Michaela Kreyenfeld (Rostock) Aart C. Liefbroer (Den Haag) Kurt Lüscher (Konstanz) Dimiter Philipov (Wien) Tomáš Sobotka (Wien) Heike Trappe (Rostock) 